\title{
O DIREITO SOCIAL AMIGO DA POBREZA E DISTANTE DO POBRE
}

\author{
Hélio de Souza Rodrigues Júnior
}

\section{Introdução}

O trabalho aqui desenvolvido pretende examinar criticamente o direito social à assistência social exatamente a partir das idéias liberais ${ }^{1}$ que direcionam e moldam esse direito, ou seja, o texto reflete criticamente sobre alguns elementos que caracterizam e orientam o direito social de combate à pobreza ${ }^{2}$, quais sejam, o de ser um direito isolado do conjunto de relações sociais e considerado fonte de desigualdade criadora. E assim fazendo, em última análise, identifica-se o motivo pelo qual dado direito social de combate à pobreza, e não um outro, rege a sociedade brasileira neste momento histórico. Sem nenhuma pretensão de identificar exaustivamente todas as características que permeiam esse direito, trata-se de refletir criticamente sobre suas bases estruturais, ou primárias, fundamentalmente integradas e coadunadas com o liberalismo. E, para tanto, procede-se a um longo diálogo com a teoria da cidadania defendida por T.H. Marshall e a particular concepção da modernidade liberal de Robert Castel.

Sublinha-se, desde logo, 3 questões: o conceito de liberalismo e neoliberalismo trabalhado neste texto; o significado da expressão examinar criticamente o direito social à assistência social; e a justificativa deste trabalho não utilizar um dado programa estatal como símbolo da assistência social. Em poucas palavras e a partir do conceito de Pierre Salama e Jacques Valier (1997, p.103), por liberalismo ou neoliberalismo relacionado aos direitos sociais de combate à pobreza entende-se a direção política no sentido de que a diminuição da pobreza é concebida como um subproduto de um crescimento econômico restabelecido graças às reformas que desestruturam e retiram a importância; a significação; o conteúdo; e a razão

\footnotetext{
* Mestrando em Direito e Políticas Públicas pelo UniCEUB, especialista em Filosofia Política pela UFC e especialista em Direito Constitucional pela UNIFOR. E-mail: rodrigues.helio@terra.com.br

${ }^{1}$ Assim é que em todo este trabalho a expressão liberalismo e neoliberalismo possui o mesmo sentido.

${ }^{2}$ Em todo este trabalho os termos direito social à assistência social e direito social de combate à pobreza são sinônimos, por ser a assistência social a pedra fundamental prevista na constituição brasileira de enfrentamento à pobreza. E, muito embora reconhecemos que tanto no plano formal como no plano real nem toda forma de combater à pobreza seja uma política de assistência social e, muito menos, nem toda política de assistência social, de fato, combata à pobreza, o modo como o tema é tratado não prejudica tal distinção. 
de ser, dos fins e das atividades intervencionistas do Estado; além da própria regulação social do trabalho, de tal modo que enquanto se espera aquele crescimento econômico, há implementações imediatas de políticas focalizadas de assistência aos extremamente pobres. Sabe-se da existência de questionamento ao uso do termo neoliberalismo ${ }^{3}$ e a estreita vinculação dada entre ele e o direito social de combate à pobreza, via as contemporâneas políticas sociais brasileiras ${ }^{4}$. Não obstante, tanto a pertinência do uso desse conceito como o estudo crítico das características do direito social umbilicalmente vinculadas ao neoliberalismo são objetos de inúmeros outros trabalhos acadêmicos, jornalísticos e políticos, perfazendo uma compreensão e um conceito já sedimentados.

Por examinar criticamente o direito social de combate à pobreza, busca-se fugir do padrão de um texto com críticas às próprias normas legais que disciplinam esse direito ou à mera administração da política social brasileira. Assim, por crítica, este trabalho quer mostrar os efeitos integradores entre a sociedade capitalista e o isolamento do direito social e a sua legitimidade, mesmo quando cria ou ampara desigualdades.

A razão pela qual não existe uma identificação e análise de uma política social específica, isto é, um dado programa estatal implantado para ser analisado e avaliado, inclusive à luz do que estabelece a constituição brasileira, deverá ser suprido em estudos complementares. Todavia, o objeto deste trabalho não é descrever o que é visível na legislação ou mostrar se um dado programa estatal obedece ou não os objetivos traçados, muito menos se, à luz das normas da constituição ele é ou não inconstitucional. A abundância dos detalhes produzidos sobre um dado programa estatal, tal como ele se apresenta, produz um certo conhecimento. E, apesar dessa análise ser válida e colacionar inúmeras vantagens de estudo, isto é diferente da finalidade deste trabalho. Ao ser apresentada a integração entre a sociedade capitalista e o isolamento do direito social e a sua legitimidade em criar desigualdades, busca-se apresentar uma outra leitura acerca da evolução dos direitos fundamentais, notadamente a dos direitos de segunda geração, bem como da própria relação entre direito social e questão social.

Assim, a primeira parte deste trabalho faz uma brevíssima explanação da relação

\footnotetext{
${ }^{3}$ Sobre esse questionamento, ver DRAIBE, Sônia M. Neoliberalismo y políticas sociales: reflexiones a partir de las experiencias latinoamericanas. Desarrollo Económico Revista de Ciencias Sociales, Buenos Aires, v. 34 , n. 134, p.181-196, jul./set. 1994.

${ }^{4}$ Sobre essa vinculação, ver também SADER, et. al. Governo Lula: decifrando o enigma. 1. ed. São Paulo: Editora Viramundo, 2004; COGGIOLA, Osvaldo. Governo Lula: da esperança à realidade. 1. ed. São Paulo: Editora Xamã, 2004; DRAIBE, Sônia M. Neoliberalismo y políticas sociales: reflexiones a partir de las experiencias latinoamericanas. Desarrollo Econômico Revista de Ciências Sociales, Buenos Aires, v. 34, n. 134, p.183, jul./set. 1994. 
entre pobreza e desigualdade social, refletindo sobre um direito social isolado do conjunto de relações sociais e considerado fonte de desigualdade criadora. As subseções analisam e submetem à crítica o direito social de combate à pobreza com base em Marshall e Castel. $\mathrm{O}$ último tópico perfaz as considerações finais, onde se compreende que as características do direito social de combate à pobreza refletem o pensamento hegemônico neoliberal. Este tópico mantém-se aberto à complementações de novas e outras reflexões, inclusive sobre questões que aqui não foram focalizadas e/ou indagadas.

\section{O direito social isolado do conjunto de relações sociais e fonte de desigualdade: uma leitura dos direitos fundamentais de segunda geração e da relação direito social e questão social}

A reflexão sobre o direito social à assistência social poderia indicar uma abordagem meramente descritiva dos elementos marcantes (característicos) desse direito social. Todavia, partindo-se do pressuposto de que o direito social à assistência social não pode ser verdadeiramente conhecido, isto é, compreendido, senão em relação a tudo o que permitiu a sua existência e o seu futuro possível. Este tipo de análise desbloqueia o estudo do direito social do seu isolamento, projeta-o no mundo real onde ele encontra o seu lugar e a sua razão de ser, e, ligando-o a todos os outros fenômenos da sociedade, torna-o solidário da mesma história social (MIAILLE, 1979, p. 19). Portanto, repita-se, trata-se de saber porque é que dado direito social de combate à pobreza, e não dado outro, rege nossa sociedade, nesse dado momento. Se a ciência jurídica apenas pode dizer como essa regra funciona, ela encontra-se reduzida a uma tecnologia jurídica perfeitamente insatisfatória. Deve-se exigir mais dessa ciência, ou melhor, exigir coisa diversa de uma simples descrição de mecanismos (MIAILLE, 1979, p. 19).

Pode-se iniciar com a seguinte formulação: se o direito social aqui recortado visa combater a pobreza, e se ele deve ser visto numa perspectiva de relação com as outras esferas do social, a sua primeira relação é com o próprio fenômeno social chamado pobreza. Ocorre que, também, se deve buscar compreender o fenômeno pobreza nessa mesma perspectiva, isto é, compreendendo-a em relação as outras esferas do social.

O termo pobreza alude a fenômenos que só podem ser explicados tendo em conta o conjunto do sistema de relações sociais. Todavia, o habitual é encontrar reflexões que pretendem reduzir o problema da pobreza a identificação de seus indicadores, cujo objetivo é medir e descrever a situação da pobreza. Geralmente, esta pratica tende a construir uma espécie de "catálogo descritivo", onde se compilam um leque de soluções para atender as particularidades de cada grupo ou categorias de pobres. Este tipo 
de análise é um problema que não envolve somente uma questão de método de combate à pobreza, mas também tem profundas implicações políticas, pois consolidaria a idéia de que a pobreza é um fenômeno autônomo e despregado do resto da sociedade e das políticas públicas. (VUOLO, 1999, p. 9, grifo do autor, tradução nossa):

Seguindo inteiramente as reflexões de Vuolo (1999, tradução nossa), quando são definidas categorias de pobreza, dilui-se a importância dos fenômenos sistêmicos desse problema, pois tudo indicaria que não há origem em comum, mas sim causas particulares da pobreza. Ao enfraquecer os vínculos entre as distintas manifestações da pobreza e os fenômenos de ordem mais global, o resultado é que com isso tais análises não submetem a pobreza à crítica de ordem econômica, ao modelo de políticas públicas que são adotadas e ao sistema de valores sociais. Para entender a pobreza em suas diversas manifestações, deve-se observar e explicar a desigualdade social. Deve-se indagar sobre os particulares processos de acumulação que historicamente foram se consolidando, daí porque o tema pobreza envolve discutir as raízes que explicam as profundas desigualdades que estão se consolidando, e outras já consolidadas, em nossa sociedade. O que interessa é saber as causas que geram desigualdades tão flagrantes entre a população, de modo que não basta a distinção e classificação dos pobres, pois também é necessário analisar os sistemas de valores e de normas que respaldam essas desigualdades, os processos econômicos globais que lhes outorgam materialidade e as estratégias políticas que lhes legitimam.

É com base nesse foco limitado sobre a pobreza que Pedro Demo (1995; 1996; 2000; 2003) colacionar duas outras questões importantes: a concepção de pobreza política e a ardil desvinculação entre pobreza e desigualdade social. Ambas interessarão diretamente o direito. No que se refere à pobreza política, as definições dadas por Demo (1995; 1996; 2000; 2003) caminham no mesmo e único sentido de afirmar que o ponto central da pobreza é a exclusão política e não a carência material. Ele não desconsidera a carência material, apenas não a formula como característica fundamental da pobreza, destacando que a pobreza surge quando os bens se tornam bens privilegiados, fruto de uma injusta distribuição que é imposta e historicamente produzida e mantida ${ }^{5}$; afinal "há que se observar que insuficiência de renda não é fenômeno dado, mas historicamente produzido, ainda que dentro de estruturas dadas"

\footnotetext{
${ }^{5}$ Diz Demo (2003, p. 36-38): “o conceito de pobreza política coloca em xeque o entendimento usual de pobreza como simples carência ou vulnerabilidade material. Por mais que esta seja decisiva, é uma delas e possivelmente não a central. O que faz alguém pobre não é propriamente a carência material, mas sobretudo a injusta distribuição dela. [...] Pobreza não se restringe à carência dada, natural, mas inclui aquela produzida, mantida, cultivada, por conta do confronto subjacente em torno do acesso a vantagens sociais, [...]. Ser pobre não é apenas não ter, mas sobretudo ser impedido de ser, o que desvela situação de exclusão injusta". 
(DEMO, 1996, p. 96), ou seja, a pobreza é manifestação da desigualdade entre os homens ${ }^{6}$. Sublinha-se que tal concepção de pobreza influirá, decididamente, nos princípios, objetivos e modelagem do direito social a ser adotado para o combate à pobreza.

Por seu turno, no que toca a segunda questão, qual seja, a ardil separação entre desigualdade e pobreza, Pedro Demo inicia sua reflexão com base em uma forte análise sobre estudos a propósito da pobreza e seu combate, dirigindo-se ao chamado "grupo IPEA" (DEMO, 2003, p. 193-274). Ele diz que é preciso questionar a separação útil entre pobreza e desigualdade. Ora, ao se vincular pobreza a uma dimensão de carência material, existe um rompimento entre pobreza e desigualdade social, apesar dos discursos presentes nesses estudos que propugnam um espectro amplo para a definição de pobreza ${ }^{7}$. Com efeito, a maneira como os estudos buscam a mensuração da pobreza pela via da carência de renda e apontam soluções na focalização dos gastos públicos, através de políticas de natureza compensatória seletiva e transferência de renda dos ricos para os pobres, fazem com que tais estudos desconsiderem o conflito que seria travado nesta distribuição de renda ${ }^{8} \mathrm{e}$, especialmente, a história do capitalismo e de suas periferias, ou seja, despreza-se o fato do país ser capitalista periférico, inclusive, desprezam-se as próprias relações internacionais de acumulação de capital. Tudo isso, continua apontando Demo, faz com que tais estudos possam imaginar que a solução para a erradicação pobreza seja técnica e não política, pois havendo recursos, bastaria distribuí-los. Neste ponto, deve-se enfrentar o seguinte dilema: se a sociedade fosse linear como os cálculos, bastaria deslocar dos ricos para os pobres os recursos necessários para a erradicação da pobreza, enquanto que a desigualdade seria apenas reduzida. Contudo, seria preciso saber que isso nem de longe resolveria o problema, porque os pobres não produziriam sua própria renda, esperariam dos ricos, além do que, se fosse possível imaginar que estes sempre concordariam em renunciar parte de sua renda, tal proposta demonstraria, nas palavras de Demo (2003, p. 219) “uma proposta compensatória e piegas”. E assim, o autor expressa que a complexidade da realidade histórica não estaria sendo tratada com seriedade, porque essa transferência não toca na questão da pobreza política (DEMO, 2003, p. 219).

\footnotetext{
${ }^{6} \mathrm{O}$ uso da expressão desigualdade entre os homens deve-se ao fato desta expressão ser de uso corriqueiro na ciência jurídica

${ }^{7}$ Demo nos diz que os estudos reconhecem que a pobreza não pode ser definida de maneira única e universal, mas trata-se de um mero reconhecimento formal, pois na prática faziam o que dados disponíveis permitiam: mensurar carências materiais, sobretudo carências de renda (DEMO, 2003, p. 212).

8 “Olvida-se que renda nunca está disponível. Está predatoriamente apropriada. Redistribuição não é função primeira da disponibilidade, mas da capacidade política de intervenção” (DEMO, 2003, p.210). 
Desse modo, quando o direito social à assistência social é estritamente vinculado à pobreza, e esta é isolada do conjunto do sistema de relações sociais, aparece a concepção de que o direito social de combate à pobreza não passa de um conjunto de receitas, ou melhor, de instrumentos ou mecanismos que ao serem aplicados corretamente cumprirão o mandamento constitucional de erradicação da pobreza (BRASIL, 1988, art. 3º, III). Tal concepção, a rigor, também isola o direito social de combate à pobreza da sociedade. Aparta-o do conjunto de fenômenos sociais que com ele está presente e forma a história social. E, acrescente-se, legitima-o perante a sociedade como um remédio que cura uma doença social chamada pobreza, pois a questão seria técnica, sem disputas políticas. Por conseguinte, existem duas questões a serem enfrentadas: o isolamento do direito social e a legitimação da desigualdade.

\section{O isolamento do direito social}

O direito social aparece como um ser externo ou alheio à sociedade, instância neutra destinada a manter a ordem social, no caso, combatendo à pobreza. A questão tange ao fato de que não se questiona a causa da pobreza. Neste sentido, "a pobreza comprova e denuncia os resultados mais desprezíveis do modo de organização das sociedades contemporâneas" (VUOLO, 2004, et. al., p. 14, tradução nossa), pois a pobreza seria um elemento constitutivo de um modo particular de acumulação de riqueza e poder social. Os pobres não estão excluídos da sociedade. Eles pertencem à sociedade e são partes das relações sociais que compõem o seu funcionamento, de modo que a pobreza não pode senão ser o resultado de valores e estratégias de ações adotadas pelos princípios organizacionais que prevalecem na sociedade 9 (VUOLO et. al., 2004, p. 14-15). Portanto, a pobreza deve ser compreendida enquanto fenômeno vinculado a particular forma de como dada sociedade é organizada, decorrência de seu sistema econômico, social, político, jurídico, cultural, etc., de modo que a pobreza não é um elemento estranho ou uma excrescência, cujo elemento apartado da sociedade, chamado de direito social, surge para combatê-la. Ambos integram a história social dessa sociedade, por exemplo, são partes dos valores e normas de como a sociedade se estrutura e produz e reproduz as suas relações sociais.

$\mathrm{O}$ direito social de combate à pobreza, com as devidas falhas que as metáforas provocam, estaria eqüidistante do pobre, mas perto da pobreza. Não se questiona se ele

\footnotetext{
${ }^{9}$ Estas assertivas decorrem do fato de que o ponto principal do trabalho de Vuolo (e outros) é o de acentuar que as políticas de combate à pobreza que hoje se apresentam são "tão pobres quanto os seus beneficiários, visto que tais políticas não visam a superação do problema, senão encerrá-lo em um espaço social delimitado e codificado de forma a ampliar as margens de tolerância social e evitar assim que se altere o normal funcionamento da sociedade" (VUOLO et. al., 2004, p. 14) 
contém elementos característicos da pobreza, inclusive de qual tipo, teor e grau. Não se indaga sobre eventual efeito indesejado ou não esperado, por exemplo, se ele pode provocar desigualdades; e se isto ocorrer, se ele pode ser assumido e quem o assumirá. Não se indaga, outrossim, se sua avaliação e controle podem alcançar certo patamar capaz de modificá-lo na essência, ou se o limite é apenas a reforma ou o aperfeiçoamento de rota. Por fim, não se indaga como este dado direito social de combate à pobreza reflete (ou não) a história social. Conseqüentemente, para que se possa compreender o nascedouro, a razão de ser, e o fim buscado pelo direito social à assistência social, deve-se rememorar a relação entre o liberalismo que sustenta o sistema capitalista e a chamada questão social, daí porque se trabalhará com os textos de Marshall e Castel. Assim, pode-se, por exemplo, formular a mesma indagação de Marshall (2002, p. 24): o direito social de combate à pobreza é antagônico à sociedade capitalista? Esta dúvida expressa a anterior pergunta chave sobre se o direito social de combate à pobreza reflete (ou não) a presente história social.

Robert Castel (2003, p. 30) informa que a expressão questão social foi explicitamente utilizada pela primeira vez em $1830^{10}$, quando foi "tomada consciência das condições de existência das populações que eram, ao mesmo tempo, os atores e vítimas da revolução industrial". Tratava-se do pauperismo, onde havia um divórcio entre a ordem jurídico-política, fundada sobre o reconhecimento dos direitos dos cidadãos, e uma ordem econômica que acarretava miséria e desmoralização das massas. E, de fato, matéria incontroversa na esfera jurídica é a derivação dos direitos sociais da chamada revolução industrial e "das desigualdades econômicas deixadas pelo liberalismo no campo econômico, que passaram a colocar em risco a liberdade política conquistada após a revolução liberal" (ARAÚJO, 2002, p. 86). É interessante observar que apesar do reconhecimento de que os direitos sociais brotam da questão social, fruto da desigualdade decorrente do liberalismo econômico, a base de sustentação do liberalismo não é questionada pelo direito social, ao contrário, ele exatamente surge como anteparo à uma convulsão social decorrente da questão social.

Difunde-se então a conviç̧ão de que aí há de fato uma ameaça à ordem política e moral, ou, mais energicamente ainda: É preciso encontrar um remédio eficaz para a chaga do pauperismo ou preparar-se para uma desordem do mundo. Entenda-se isso como o fato de que a sociedade liberal

\footnotetext{
${ }^{10} \mathrm{O}$ autor, todavia, adverte que uma questão social já existia nas sociedades européias ocidentais pré-industriais, através de múltiplas formas institucionalizadas de relações não mercantis a distintas categorias de indigentes (as práticas e as instituições de assistência), e também alguns tipos de intervenção, tais como repressão da vagabundagem, obrigação do trabalho, controle de circulação de mão-de-obra. (CASTEL, 2003, 3. ed., p. 31). 
corre o risco de explodir devido às novas tensões sociais que são a conseqüência de uma industrialização selvagem. (CASTEL, 2003, p. 30)

$\mathrm{O}$ direito social surge como um contraponto àquele problema provocado pelo liberalismo, ou seja, a pauperização, e não ao próprio liberalismo. Ademais, é pouco salientado que o direito social pode ser visto como um mecanismo desse liberalismo, isto é, o direito social faz parte da história social, não como elemento isolado, externo, considerado neutro, pelo contrário, ele está inserido na sociedade de onde nasce, integrando os mecanismos que produzem e reproduzem as relações sociais. Tal pode ser visto no bojo da teoria de Marshall e Castel:

O ponto de partida da teoria evolutiva da cidadania de Marshall envolve "um duplo processo, de fusão geográfica e de separação funcional, justamente porque àqueles três direitos (civil, político e social) formavam um só direito, e eles estavam unidos porque as instituições estavam amalgamadas" (MARSHALL, 2002, p. 10). Portanto, aqui já se reconhece que há um direito social anterior a todo o processo evolutivo que sustenta a própria teoria da evolução da cidadania, muito embora ele esteja entrelaçado com outros direitos; tanto que o próprio Marshall (2002, p. 11, grifos do autor) diz que após aquele processo de fusão geográfica e separação funcional "os direitos sociais que tinham se enraizado na participação da comunidade na vila, na cidade e nas guildas foram gradativamente dissolvidos pela mudança econômica, até que nada restou senão a Poor Law". É interessante notar o duplo papel desempenhado pela lei dos pobres que o próprio Marshall assinala ${ }^{11}$ : a primeira ação foi no sentido de que a lei dos pobres findou por englobar, ao lado das práticas meramente beneficentes, um sistema de regulamentação de salários concebidos no plano nacional e administrados localmente, de modo que:

A Poor Law elisabetiana era, afinal de contas, um item num amplo programa de planejamento econômico cujo objetivo geral não era criar uma nova ordem social, e sim preservar a existente com um mínimo de mudança essencial. À medida que o padrão da velha ordem foi dissolvido pelo ímpeto de uma economia competitiva e o plano se desintegrou, a Poor Law ficou numa posição privilegiada como sobrevivente única da qual, gradativamente, se originou a idéia dos direitos sociais. Mas, no fim do século XVIII, houve uma luta final entre a velha e a nova ordem, entre a sociedade planejada (ou padronizada) e a economia competitiva. [...] Neste breve episódio de nossa história, vemos a Poor Law como a defensora agressiva dos direitos sociais da cidadania. (MARSHALL, 2002, p. 17-18, grifos do autor).

\footnotetext{
${ }^{11} \mathrm{O}$ que por si só indica que o direito social de combate à pobreza não está isolado da história social, bem como não está acima ou eqüidistante das autoridades políticas, como pressupõe a teoria da geração de direitos fundamentais. 
Existia, então, uma forte conotação de utilizar o direito social para manter a ordem medieval contra as forças do mercado competitivo, leia-se, liberalismo, que abriria espaço para a definitiva implantação do capitalismo. Portanto, o direito social aqui cumpre, no mínimo ao lado dos meios para enfrentar a pobreza, um contraponto à necessidade da liberalização do mercado e da implantação do princípio da igualdade, inclusive para a livre celebração de contratos. Se for verdade que o direito social da lei dos pobres não pode ser considerado representação da cidadania ou do direito social de segunda geração, é imprescindível relativizar tal apego a tão dogmática classificação: seja porque, no essencial, a lei dos pobres daquela época objetivava atenção à pobreza e indigência, qualquer que fosse o meio adotado, de beneficência ou repressão; seja porque a legislação elisabetiana tinha feito dela algo mais do que um meio para aliviar a pobreza e suprimir a vadiagem, e "seus objetivos construtivos sugeriam uma interpretação do bem-estar social que lembrava os mais primitivos, porém mais genuínos, direitos sociais [...]” (MARSHALL, 2002, p. 17-18).

Posteriormente, em 1834, essa lei dos pobres passou por uma alteração legislativa e "renunciou a todas as suas reivindicações de invadir o terreno do sistema salarial ou de interferir nas forças do mercado livre" (MARSHALL, 2002, p. 19), conseqüentemente, a segunda ação ou, como foi citado, o duplo papel, indica que "a Poor Law se constituiu num auxílio, e não numa ameaça, ao capitalismo, porque eximiu a indústria de toda a responsabilidade que não fizesse parte do contrato de trabalho" (MARSHALL, 2002, p. 27), ao passo que aumentou a competição no mercado de trabalho.

Entretanto, mesmo diante da compatibilidade entre a lei dos pobres e o liberalismo, as medidas de combate à pobreza não puderam ser concebidas como direitos sociais dos pobres, o que afasta a noção de cidadania. Na verdade, a adoção da lei dos pobres era uma alternativa à cidadania, justamente porque as reivindicações dos pobres só seriam atendidas se eles deixassem de ser cidadãos (MARSHALL, 2002, p. 19). E ele nos dá dois exemplos, o dos indigentes que deveriam abrir mão, na prática, do direito civil da liberdade pessoal devido ao internamento na casa de trabalho, e assim eram obrigados por lei a abrir mão de quaisquer direitos políticos. E o segundo exemplo, foram as primeiras leis que regulamentaram as atividades fabris (Factory Acts), haja vista que apesar da melhoria das condições de trabalho e redução da jornada de trabalho, tal legislação era destinada às mulheres e crianças e não aos homens adultos, evitando-se, assim, afronta ao direito civil de efetuar um contrato de trabalho livre. "As mulheres eram protegidas porque não eram cidadãs. Se desejassem gozar da cidadania com todos os seus direitos, tinham de desistir da proteção" 
(MARSHALL, 2002, p. 19-20). Portanto, a lei dos pobres ou o direito social de combate à pobreza dessa época também não seria hodiernamente chamado de direito social, por excluir ao invés de incluir, e não ter o pressuposto de que cidadania é o direito do cidadão de participar integralmente da comunidade política (MARSHALL, 2002).

Quando Robert Castel discorre sobre o advento da modernidade liberal e o elo com a questão social, ele aponta que "dois novos dados modificam, a partir do fim do século XVII e do início do século XVIII, o modo como se apresenta a questão do lugar ocupado pelos grupos mais desfavorecidos" (CASTEL, 2003, p. 213), a saber: a vulnerabilidade de massa e a liberdade do trabalho. Ele irá contar que o direito social de combate à pobreza, em um primeiro momento, contou com forte apoio do Antigo Regime, onde o trabalho era regulado e tutelado, para em um segundo momento cristalizar a incompatibilidade entre trabalho regulado e o livre mercado, onde a liberdade do trabalho devia ser assegurada. Assim, é que quando o trabalho era regulado e tutelado, descobriu-se a vulnerabilidade das massas. E somente a liberdade do trabalho poderia trazer segurança e proteção social às massas. Todavia, é importante fazer uma advertência no sentido de que o próprio Castel (2003, p. 213) reconhece que, se por um lado, a vulnerabilidade das massas nascia do excesso de regulações e tutelas do trabalho, pelo outro lado, tal vulnerabilidade também aparece suscitada pelo enfraquecimento dessas proteções e regulamentos. Entretanto, não era esse o pensamento da época.

De qualquer modo, para que se perceba essa dupla função do direito social de combate à pobreza, Castel (2003, p. 219) diz que o discurso sobre a indigência insiste no caráter de massa do fenômeno. E o pior é que tanto a "consciência de que uma vulnerabilidade de massa persiste e até mesmo se acentua, enquanto a situação econômica e social melhora" (CASTEL, 2003, p. 222), como a situação caótica e recessiva, na França, no ano de 1760, ambos indicam que "nunca aparecera com tamanha evidência a defasagem entre os modos de apresentar, de agora em diante, a questão social e a assistência tradicional" (CASTEL, 2003, p. 225). Estava dada a partida para que ao lado dessa tomada de consciência de uma vulnerabilidade de massa, pudesse ocorrer uma transformação da concepção do próprio trabalho:

A verdadeira descoberta que o século XVIII promove não é, pois, a da necessidade do trabalho mas, sim, a da necessidade da liberdade de trabalho. Implica a destruição dos dois modos de organização do trabalho até então dominantes, o trabalho regulado e o trabalho forçado. [...] Toda a ideologia 'liberal' está nessas poucas linhas: a liberdade de trabalho deve libertar também a iniciativa privada, o gosto pelo risco e pelo esforço, o 
sentido da competição. $\mathrm{O}$ desejo de melhorar sua condição é um motor do qual o empenho não se pode privar. [...] A ruptura com a sociedade estamental, de status, de condições, regidas pelas tutelas, é total. (CASTEL, 2003, p. 232-234, grifos do autor)

Através da intricada teia entre trabalho regulado e trabalho livre, Castel apresenta que a questão social foi vinculada às restrições ao livre mercado. Resolver a pobreza era assegurar acesso livre ao trabalho, ou melhor, garantir que a pobreza seria solucionada com a eliminação de todos os tipos de privilégios que impedissem o pleno desenvolvimento do mercado, sejam obstáculos advindos das regulações do trabalho, sejam obstáculos originados de concessões vitalícias incompatíveis com o livre jogo do mercado competitivo. Desta feita, os privilégios das corporações de ofícios e das profissões eram obstáculos para a superação da pobreza. Somente com liberdade, no caso, de acesso ao mercado de trabalho, era possível que os indigentes encontrassem um lugar na sociedade. É importante perceber que conviviam de modo conflituoso elementos feudais predominantes com elementos do liberalismo econômico e político. Este, a todo custo, buscava ser hegemônico. Ademais, é bom lembrar que Castel esclareceu que a revolução industrial não foi o nascedouro exclusivo dos problemas contidos na chamada questão social (CASTEL, 2003, p.31), não obstante tenha aumentado, e muito, o pauperismo depois dessa revolução.

De qualquer modo, é bom frisar que Castel não nega a existência de uma preocupação com a assistência social por parte dos revolucionários burgueses ${ }^{12}$, ao contrário, o antagonismo real entre a regulação do trabalho e a pobreza serviu de ferramenta para os revolucionários defenderem a liberdade de acesso ao trabalho, indo de encontro as guildas, corporações de ofício e outras instituições que davam suporte ao Antigo Regime. O que ele informa é que essa preocupação é de mão única, e funciona da seguinte maneira: o indigente é reintroduzido no pacto político se, e somente se, trabalhar; vez que torna-se um cidadão útil e virtuoso. Porém, e aqui está o grande dilema, não há pacto social para lhe assegurar essa possibilidade, de maneira que a obrigação de trabalhar é atribuição, exclusiva, do próprio indigente (CASTEL, 2003, p. 258). Constata-se, então, que a desigualdade social é atribuída ao próprio pobre e não ao sistema de relações sociais em que ele vive.

É baseado no longo debate historiado e analisado por Castel (2003, p. 259-264) sobre a não obrigação da sociedade e/ou do governo garantir um trabalho ao cidadão que o direito social de combate à pobreza irá, plenamente, conformar-se. Utiliza-se o termo plenamente porque o primeiro plano da sua conformação se dá naquela perspectiva de que

\footnotetext{
${ }^{12}$ Ver comentário de Castel sobre o relatório do Comitê sobre a Mendicância e Lei Le Chapelier (CASTEL, 2003, p. 250-251), e relatório de Jean-Baptiste Bô sobre a extinção da mendicância (CASTEL, 2003, P. 258). 
somente através da liberdade de acesso ao trabalho é que a pobreza poderia ser enfrentada. Essa conformação somente se perfaz com a não obrigatoriedade da sociedade e/ou do governo garantir um trabalho ao cidadão. Ora, o liberalismo combatia as tutelas e regulações do trabalho como fator de enfrentamento da pobreza. A garantia de um trabalho ao indivíduo era uma tutela do trabalho, inclusive foi muito combatida. Ela representaria um retrocesso, uma incoerência com as diretrizes do liberalismo. E não é só: o liberalismo repudiava todas as regulações fruto de privilégios e status que impedissem o acesso ao livre jogo do mercado. $\mathrm{O}$ motor do progresso e do desenvolvimento era o incentivo alcançado pelo próprio empenho, mérito conquistado pelo indivíduo, seja ele o detentor dos meios de produção ou livre vendedor de sua força de trabalho. A certeza de um trabalho enfraqueceria a premiação pelo mérito em favor de um privilégio. Ademais, para se viabilizar o mercado, permitindo a livre circulação das mercadorias e a acumulação ilimitada das riquezas, era também preciso proteger as trocas. E o instrumento das trocas era o contrato. Todavia, não era qualquer troca/contrato, mas a liberdade de troca ou a liberdade contratual, situação incompatível com qualquer tipo de regulação ou tutela que interfira nessa liberdade, inclusive a relação contratual entre patrões e trabalhadores. Por fim, para a existência de uma sociedade de livre mercado, é necessário que os produtos do trabalho sejam trocados em função de seu custo, pois o liberalismo advoga que é a troca quem promove o justo equilíbrio dos interesses dos parceiros. Portanto, é condição de uma sociedade de livre mercado que os produtos sejam trocados em função de seu valor-trabalho, desde que produzido, ele próprio, por um trabalho livre. Não há espaço, então, para trabalhos forçados, tutelas e regulações que constituiriam feudalidades privilegiadas que captariam as riquezas, impondo trocas desiguais (CASTEL, 2003, p. 231).

A questão enfrentada por Castel (2003, p. 242-248) decorre da dissociação entre o direito de livre acesso ao trabalho e o direito a um trabalho. O Antigo Regime não compreendeu que a indigência suscitava um problema de direito, pois sempre se pensou em fazer caridade aos pobres, jamais em fazer valer os direitos do pobre em relação à sociedade e os da sociedade em relação a ele ${ }^{13}$. "Porém, a aplicação desse direito se desdobrava conforme 'esses homens sem subsistência' sejam capazes ou não de trabalhar' (CASTEL, 2003, p. 243, grifos do autor). Ou seja, há uma classificação da pobreza, e o critério de separação da pobreza era entre pobres válidos e pobres inválidos. A assistência era uma prerrogativa dos incapazes de trabalhar e, ainda assim, desde que fossem domiciliados. O pobre podia ser

\footnotetext{
${ }^{13}$ Com base em tal formulação seria possível o uso da expressão cidadania. 
inválido, mas tinha de ter domicílio. Tinha de residir em lugar fixo, o que afastava pontes, logradouros públicos, proximidades das feiras, mercados e a própria área descampada próxima das cidades. Castel (2003, p. 244-245) fala que a dupla condição a preencher é familiar: a territorialização e a invalidez. Por outro lado, os pobres válidos dependiam de um tratamento completamente distinto, pois a modernidade liberal admitia como princípio incontestável que os pobres válidos deveriam ser ajudados apenas através do trabalho, ao invés de puni-los ou de obrigá-los a trabalhar. O problema é que, como já aduzido, o livre acesso ao trabalho substituiu a obrigação disciplinar de trabalhar. E bastava eliminar todas as barreiras construídas pelo feudalismo contra a abertura do mercado de trabalho (CASTEL, 2003, p. 246).

Com efeito, da leitura anterior de Marshall e Castel que se pode indagar para além da diferença entre responder à causa da pobreza e dar resposta ao fenômeno da pobreza, de modo a não encobrir a questão política que envolve o direito social, devendo ser considerado o modo de organização social da sociedade, ou seja, o seu modo de produção, seus princípios, normas, valores, cultura que produzem e reproduzem riquezas e privilégios somente para alguns. Assim, o direito social vincula-se muito mais com a desigualdade entre os indivíduos do que com a pobreza, pois excluída a desigualdade natural, relacionada a fatores físicos e biológicos $^{14}$, a desigualdade provocada pela forma como a sociedade está estruturada indica que a pobreza é apenas um efeito colateral da organização social, e seria muito pobre um direito que buscasse apenas essa correção. Por outro lado, não se pergunta: até que ponto a pobreza e o direito social são objetos essenciais e integram a forma de organização social? Até que ponto a pobreza não é uma excrescência, um resíduo, mas componente da engrenagem social, tal como o direito social? Por conseguinte, foi visto como Marshall e Castel apresentaram o duplo uso do direito social ou da legislação que visava resolver a questão dos pobres, tanto pelo Antigo Regime como pelo liberalismo então emergente, cujo resultado foi a manutenção da divisão da sociedade e a própria classificação dos pobres. E é aqui, neste ponto, que o direito social aparece como um elemento isolado da sociedade, significando dizer que ele aparece para solucionar problemas da sociedade. E somente nisto consiste o seu vínculo com a sociedade em que ele está sedimentado. Nenhuma questão é levantada, por exemplo, sobre controle social e manutenção da produção e reprodução de

\footnotetext{
14 "O exemplo da insuficiência de chuvas no Nordeste poderia ser ilustrativo. Enquanto se tratar do fenômeno natural de falta de chuva, a rigor não há pobreza [...]. Não chove para todos, indiscriminadamente. Pobreza surge na 'indústria da seca', quando algo em si natural é usado politicamente para a reprodução histórica de privilégios em favor de minorias" (DEMO, 1996, p. 97-98). 
riquezas e privilégios, tal como elas se apresentam, pois ele cuida somente da indigência ou da miséria. Em suma, observa-se que a separação entre pobreza e desigualdade provoca no direito social o maléfico efeito de tergiversar sobre a dimensão política da matéria, escondendo-se atrás de idílico tecnicismo sobre geração de direitos fundamentais.

No que toca a questão da geração de direitos fundamentais, não são motivos de debates na esfera jurídica o entendimento de que os direitos sociais foram inicialmente consubstanciados nas constituições dos Estados somente no século XX, através da constituição mexicana em 1917 ou alemã, de 1919, conhecida como "constituição de weimar"; e de que não é rigoroso identificar os chamados direitos sociais como direitos especificadamente empregatício. Basta pensar que o direito à seguridade social é hoje em dia, em numerosos países, patrimônio dos cidadãos, assim como o direito à moradia ou à educação, para aceitar sem reservas que o social não é patrimônio dos empregados (SUÁREZ, 1977, p. 205, tradução nossa). De qualquer maneira, sublinhe-se que diversos juristas ${ }^{15}$ adotam o entendimento de que houve uma evolução histórica dos direitos fundamentais e que existe uma geração (ou dimensão) de direitos fundamentais ${ }^{16}$, sendo certo que o direito social está inserido nesse processo evolutivo.

É bastante elucidativo o ponto de interseção entre a concepção de gerações de direitos fundamentais e a obra de Marshall, seja do ponto de vista da evolução da cidadania, seja do ponto de vista das contradições do próprio direito social de combate à pobreza, que como já assinalado, pode exercer duplo papel. Contudo, no que toca a primeira questão, é todo evidente a identificação entre a concepção de geração de direitos fundamentais e o desenvolvimento da cidadania formulado por Marshall. Ele, desde logo, inicia sua tese dividindo o conceito de cidadania em três partes ou elementos. E chama "estas três partes, ou elementos, de civil, política e social" (MARSHALL, 2002, p. 9). O elemento civil é composto dos direitos necessários à liberdade individual; enquanto que o elemento político compreende

\footnotetext{
${ }^{15}$ Cf. KRELL, Andréas J. Direitos sociais e controle judicial no Brasil e na Alemanha: os (des) caminhos de um direito constitucional comparado. Porto Alegre: Sergio Antonio Fabris Editor, 2002; BONAVIDES, Paulo. Curso de direito constitucional. 5. ed. São Paulo: Malheiros, 1994; ALEXY, Robert. Teoria de los derechos fundamentales. Madrid: Centro de Estúdios Constitucionales, 1993; CONOTILHO, José J. G. Direito Constitucional. 6. ed. rev. Coimbra: Ed. Almedina, 1993.

${ }^{16}$ Podemos compreender a evolução dos direitos fundamentais da seguinte maneira: "os direitos fundamentais foram, de início, concebidos como direitos da liberdade. Eles diziam respeito aos direitos civis e políticos [...] surgiram juntamente com os movimentos constitucionalistas e liberal do século XVIII. [...] Os direitos fundamentais de segunda geração são os direitos sociais, culturais e econômicos, bem como os chamados direitos coletivos, introduzidos nas diferentes formas do Estado social. [...] são obrigações positivas do Estado. [...] No final do século XX, surge uma terceira geração de direitos fundamentais, não mais com a finalidade de proteger interesses individuais ou coletivos, mas com o intuito de preservar o gênero humano [...] garantindo o desenvolvimento, à paz, o meio ambiente saudável e à comunicação”. (ARAÚJO, 2002, p.85-87).
} 
o poder de participar do exercício do poder político, seja como membro investido de poder político ou como eleitor. Ambos elementos correspondem a noção de direitos fundamentais de primeira geração. O elemento social, por sua vez, "vai desde o direito a um mínimo de bemestar econômico e segurança ao direito de participar, por completo, na herança social e levar a vida de um ser civilizado de acordo com os padrões que prevalecem na sociedade" (MARSHALL, 2002, p. 9). Diante de conceito tão amplo, cuja definição expressamente faz a extrapolação dos direitos sociais e econômicos, torna fácil vinculá-lo aos chamados direitos fundamentais de segunda e terceira geração. Por conseguinte, as três diferentes maneiras de a cidadania existir corresponde às três gerações de direitos fundamentais ${ }^{17}$.

O que se denota é uma concepção de evolução linear, gradativa e seqüencial da cidadania e dos direitos, tanto que Marshall (2002, p. 9) nos diz que sua análise é "ditada mais pela história do que pela lógica". É fonte de crítica o pressuposto de que cada um desses elencos de direitos sirva como ponto de apoio para a conquista do elenco seguinte, via processo de conquista de direitos em escada, o que sugere a idéia de uma evolução natural da cidadania (SAES, 2003, p. 3) ${ }^{18}$. De igual maneira, a concepção de gerações de direitos fundamentais colaciona o pressuposto de que é possível contar a sua história no bojo da história da formação da tradição jurídica do ocidente, também de modo linear e sempre pairando um vetor de desenvolvimento evolutivo.

Berman (1996, p.16-17, tradução nossa) diz que falar de uma tradição do direito no ocidente é chamar atenção para dois fatos importantes: primeiro, que no final do século XI e no curso do século XII as instituições jurídicas do ocidente se desenvolveram continuamente ao longo de gerações e séculos, onde cada geração edificava conscientemente sobre o trabalho de gerações anteriores; e, segundo, que este processo consciente de desenvolvimento contínuo é concebido não como um processo de simples mudanças, senão de desenvolvimento orgânico. Daí porque, dentre outras características apontadas para o que comumente se chama de tradição jurídica do ocidente, Berman (1996, p. 18-19, tradução nossa) continua nos dizendo que essa tradição concebe o direito como um todo coerente, como um sistema integrado ou como um corpo, o que pressupõe que este corpo se desenvolve ao longo do

\footnotetext{
17 Cf BONAVIDES, Paulo. Curso de direito constitucional. 5. ed. São Paulo: Malheiros, 1994 e CONOTILHO, José J. G. Direito Constitucional. 6. ed. rev. Coimbra: Ed. Almedina, 1993.

${ }^{18}$ Saes (2003, p. 12) colacionar a idéia de que a perspectiva de Marshall desconsidera que a maioria social é dinâmica e progressiva, e a perspectiva das classes dominantes é estagnacionista e regressiva, o processo de criação de direitos na sociedade capitalista é necessariamente um processo conflituoso, embora não contraditório. Ele cita Göran Therborn como quem melhor conceituou essa dinâmica, na medida que seriam as lutas populares, desde que potenciadas pelas dissensões internas das classes dominantes nos planos nacional e internacional, o fator determinante no processo global de criação de direitos na sociedade capitalista.
} 
tempo entre gerações e séculos. Aliás, o próprio conceito de corpo ou sistema de direito dependeu, para sua validade, da fé no caráter continuado da lei, em sua capacidade de desenvolver-se ao longo das gerações e séculos. O sistema de direito somente sobrevive porque contém um mecanismo integrado para as mudanças ou alterações orgânicas. Assim, continua o autor (BERMAN, 1996, p. 18), acredita-se que o direito tem uma lógica interna. As mudanças não somente são adaptações do antigo ao novo, senão que formam, elas mesmas, uma pauta de reformas. Todo o processo está sujeito a certas regularidades e, ao menos em retrospectiva, refletem uma necessidade interna. Ou seja, "há claramente o pressuposto de que as mudanças não ocorrem ao acaso, senão que procedem por uma reinterpretação do passado para satisfazer as necessidades atuais e do futuro" (BERMAN, 1996, p.19). Assim, o direito é contínuo e tem uma história. E a historicidade do direito vai unida à concepção de sua supremacia sobre as autoridades políticas ${ }^{19}$ (BERMAN, 1996, p.19).

Todavia, ao final, o que o Berman busca romper é com a visão linear da história do direito, introduzindo elementos de ruptura e descontinuidades, de modo que "la historicidad del derecho em Ocidente no debe confundirse com el historicismo, en el sentido de esclavitud al 'ciego poder' (según lá expresión de Nietzche) del pasado" (BERMAN, 1996, p. 26, grifo do autor). Sem adentrar na polêmica da pós-modernidade sobre irracionalidades e ausência de forças resultantes que possam exprimir a totalidade social, sem dúvida alguma que é acertada a idéia de que os processos históricos são conflituosos, e que a história dos direitos fundamentais não é cartesiana, apesar de ser assim contada.

A par disso, deve-se chamar atenção para o fato de que o nexo de causa e efeito entre a questão social e o direito social se dá, para os juristas, com a áurea da descendência e, por isso mesmo, com a respeitabilidade que envolve o vínculo a um antepassado comum. É que a perspectiva de gerações de direitos fundamentais faz com que o direito seja concebido como isolado da história social, apesar do discurso ser exatamente o contrário. Ora, a despeito da menção dos juristas à relação entre direito social e questão social, o próprio conceito de geração indica um conjunto de funções ou fenômenos pelos quais um ser organizado produz outro semelhante (FERREIRA, 1986 p. 847). A maioria dos juristas entende que o ordenamento jurídico é elemento exclusivo do direito, pois ele é concebido como um conjunto de princípios e normas que estabelece o que é o direito e como o próprio direito deve ser

\footnotetext{
${ }^{19} \mathrm{E}$ é neste ponto da passagem de Berman que se pode, novamente, chamar atenção: que se evite algum pretenso entendimento sobre a neutralidade do direito, no caso, que o direito social não reflita a história social de uma dada sociedade. 
criado, ou seja, há uma identificação entre direito e ordenamento jurídico, de modo que é o próprio direito quem diz o que é direito e como são gerados outros direitos. Portanto, não existem relações sociais, econômicas, políticas, culturais, etc. Haverá apenas uma sensibilidade ao clamor da sociedade.

O pressuposto da concepção de gerações de direitos fundamentais é um direito eqüidistante dos problemas sociais, ou seja, uma instância apartada da sociedade e capaz de oferecer-lhe os melhores remédios ou meios para uma convivência justa e harmônica. O direito não é visto como um mecanismo dessa própria sociedade, mas criado por esta sociedade para resolver uma questão, no caso, a questão social. E, enquanto mecanismo, ele é separado do problema questão social, ou seja, representa uma peça trazida de fora da sociedade, instância neutra do Estado, e introduzida para resolver um problema, e não, por exemplo, uma peça vinculada ou que interage com o próprio problema. $\mathrm{O}$ único toque entre o direito e a sociedade em que ele está inserido é a concepção de que ele atende aos reclames da sociedade e tornou-se um instrumento para a paz social. Dado um fato na sociedade, o direito surge para discipliná-lo.

Aliás, apesar de fugir do objeto deste trabalho, pode-se rapidamente lembrar aquela passagem de que os direitos sociais só foram incorporados às cartas constitucionais no século XX, muito embora a questão social tenha sido o dilema do século XIX. E o advento dos direitos sociais coincide com o período em que se apregoou e foi dado início ao intervencionismo estatal na economia, via políticas keynesianas, como instrumento de recuperação da economia capitalista após a crise de 1929. Por conseguinte, é evidente a relação entre as cartas constitucionais liberais introduzindo direitos sociais e um liberalismo que exigiu a intervenção estatal na economia, com o Estado empreendendo, planejando e financiando. Essa relação mereceria, no mínimo, indagações e reflexões especiais, visto que tanto as políticas keynesianas como os direitos sociais fomentaram a economia capitalista a sair da crise de 1929, mantendo-a para as gerações futuras. Por seu turno, a própria concepção de direitos fundamentais por gerações conota o direito como um direito que sucede a outro em um ciclo vital, uma espécie de posteridade genealógica.

Em suma, a concepção de que o direito social é exclusivamente estirpe das declarações de direitos das revoluções liberais enfraquece a relação de causa e efeito pretendida pelos juristas entre o direito social e a questão social, seja porque essas declarações liberais foram utilizadas como ponto fundamental para o pleno desenvolvimento e expansão do capitalismo, que é inquestionavelmente apontado como matriz de desigualdade; seja 
porque novamente traz a idéia de que ele é um mecanismo, um instrumento, um remédio para os males sociais, apartado da história social. O direito social visará combater os efeitos da questão social e não as causas da questão social. A concepção de gerações de direitos reforça a noção de que o único toque ou vínculo entre a história social e o direito é que, dado um fato, o direito irá discipliná-lo, pois sendo sensível ao clamor da sociedade, de pronto ele encontrará uma solução para enfrentar ou responder a tal clamor. Mas tal pressuposto indica que ele permanece alheio ao mundo ao seu redor, com uma grande capacidade de não se envolver, por exemplo, pelos fatores que geram as desigualdades sociais. Trata-se, apenas, de uma relação técnica. E, a partir daqui, também não é submetido a nenhuma crítica à economia política.

\section{O direito social como fonte de desigualdades}

A segunda questão a ser enfrentada diz respeito ao fato de que o direito social de combate à pobreza legitima-se perante a sociedade. E esta legitimação decorre da concepção de que a desigualdade deve ser mantida, pois é vista como fonte de progresso ou desenvolvimento social, ou seja, a desigualdade social é elemento positivo para a sociedade. Evidentemente que não se trata da conhecida concepção de Pedro Demo no sentido de que "a desigualdade social é um dos motores da história, porque não se trata de algo a ser reconhecido com vistas apenas em manter, mas de algo a ser reconhecido visando sobretudo a combater" (DEMO, 1987, p. 26), ou seja, diz o autor que a relação social é sempre desigual e, por isso, polarizada, onde de um lado há organizações institucionalizadas de base física e de estilo cultural e não material buscando a persistência temporal, através da lógica da autodefesa e da preservação; e no seu oposto estaria a lógica do oprimido, isto é, a busca pela inversão da ordem, da desinstitucionalização (DEMO, 1987, p. 34). É através desse caminhar polarizado que ele reconhece a desigualdade como um dos motores da história ${ }^{20}$.

Não obstante, a leitura de Marshall e Castel que será apresentada mostra uma opção por parte desses autores em direção contrária, buscando uma adesão do oprimido à lógica da preservação ou da autodefesa. Ora, muito embora se possa ver, tanto na teoria de Marshall como na de Castel, conflitos entre desiguais, o que movimentaria a história social, a evolução da cidadania de Marshall encontra seu perímetro, ou sua zona de atuação, no

\footnotetext{
20 "Imaginar a desigualdade eliminável da história não nos parece uma visão dialética, porque inserimos na história componentes que já não admitiriam a transição histórica. Se supomos que a história se transcende por ser conflituosa, não faz sentido imaginar, a partir de certo ponto, uma história não conflituosa" (DEMO, 1987, p. 34) 
equilíbrio entre um direito social que corresponda, proporcionalmente, à renda real do cidadão, com base em valor de mercado (MARSHALL, 2002, p. 40), enquanto que, por seu turno, o Estado social de Castel é um compromisso moral entre os interesses de mercado e as reivindicações do trabalho (CASTEL, 2003, p. 280), o que de pronto ensejaria algumas dúvidas, tais como, diante do enfraquecimento do Estado e das relações de trabalho, como buscar uma regulamentação ou controle sobre o interesse do mercado? Em outras palavras: em troca de quais vantagens o mercado aceitaria um pacto desfavorável à sua lógica? A questão aqui seria procurar um fundamento sólido e a sustentabilidade histórica para quaisquer das propostas de pacto ou compromisso.

Acentuou-se, em linhas anteriores, que em Marshall a medida adotada para combater à pobreza era separar os pobres, ao menos, em duas categorias: os pobres livres para contratarem a venda de sua força de trabalho e os pobres não cidadãos. As medidas de combate à pobreza eram destinadas somente a estes últimos. É importante perceber, ainda, dois aspectos: primeiro, que o próprio Marshall (2002, p. 26) lembra que nessa época considerava-se a desigualdade social como necessária e proposital. Segundo, que ele mesmo concebe legitimidade às desigualdades, desde que no bojo do que ele chama de desigualdades permitidas.

De fato, Marshall (2002, p. 33) segue a sua linha evolutiva e muito embora reconheça que a cidadania, mesmo no final do século XIX, pouco fez para reduzir a desigualdade social, foi ela quem ajudou na formulação do processo que conduziu às políticas igualitárias do século XX. Assim é que ele acredita que o que era privilégio e monopólio de uns poucos, foi posto ao alcance de muitos. "A diminuição da desigualdade social fortaleceu a luta por sua abolição, pelo menos com relação aos elementos essenciais do bem-estar social" (MARSHALL, 2002, p. 40), daí porque ele começa a refletir sobre o objetivo e alcance do direito social, na exata razão em que este passou a "incorporar um direito universal a uma renda real que não é proporcional ao valor de mercado do reivindicador" (MARSHALL, 2002 , p. 40). Formulada a premissa, ele efetivamente reflete sobre o objetivo e alcance do direito social:

O objetivo dos direitos sociais constitui ainda a redução das diferenças de classe, mas adquiriu um novo sentido. Não é mais a mera tentativa de eliminar o ônus evidente que representa a pobreza nos níveis mais baixos da sociedade. Assumiu o aspecto de ação modificando o padrão total da desigualdade social. Já não se contenta mais em elevar o nível do piso do porão do edifício social, deixando a superestrutura como se encontrava antes. Começou a remodelar o edifício inteiro e poderia acabar transformando um arranha-céu num bangalô. É, portanto, importante 
considerar-se se tal objetivo final encontra implícito na natureza desse desenvolvimento ou se, como assinalei acima, há limites naturais à tendência contemporânea para uma maior igualdade social e econômica. (MARSHALL, 2002, p. 40).

Marshall utiliza duas metáforas para responder tal questão, a do planejamento urbano e a do direito à igualdade de oportunidade via escolaridade, para depois ser categórico em sua resposta: as desigualdades permitidas devem ser aceitas, pois benéficas para a sociedade. A metáfora do planejamento urbano é considerada oportuna pelo próprio Marshall (2002, p. 51) porque uma política habitacional implica e abrange aspectos gerais de uma comunidade inteira, de modo que os direitos individuais deverão ceder, além do fato de que uma política habitacional não é destinada a um setor da camada inferior da escala social, muito menos a um tipo específico de necessidade (MARSHALL, 2002, p. 51). Trata-se, continua o autor, de uma comunidade equilibrada, ou seja, uma sociedade que contenha uma adequada mistura de todas as classes sociais, assim como de grupos etários, sexuais e ocupações. O objetivo dos planejadores urbanos, tal qual seria o objetivo dos planejadores da cidadania, "não é uma sociedade sem classes, mas uma sociedade na qual as diferenças de classe sejam legítimas em termos de justiça social" (MARSHALL, 2002, p. 51); de modo que essa metáfora representa "um exemplo da maneira pela qual a cidadania está em si mesma se tornando o elemento criador da desigualdade social” (MARSHALL, 2002, p. 51).

Por seu turno, o direito à igualdade de oportunidade via escolaridade tratada por Marshall (2002, p. 54-55) pode ser resumido no direito do cidadão de participar, efetivamente, de um processo de seleção e mobilidade social, abolindo privilégios hereditários, isto é, "permitir que o jovem desprovido de recursos mostre que é tão capaz quanto o rico" (MARSHALL, 2002, p. 54), uma vez que a igualdade de oportunidade é oferecida a toda criança quando do seu ingresso na escola, desde a menor idade até passar por etapas intermediárias e avançadas e por processos classificatórios. É na escola que a oportunidade começa a ficar desigual, e as alternativas, limitadas.

O processo é, algumas vezes, associado com idéias de individualismo do tipo laissez faire, mas, no que toca ao sistema educacional, se trata de uma questão não de laissez faire, mas de planejamento. O processo pelo qual habilidades são reveladas, a cujas influências estão sujeitas, os testes pelos quais são mensuradas e os direitos concedidos com base nos resultados dos testes são todos planejados. [...] No final das contas, a mistura de sementes variadas, originariamente colocada na máquina, surge em pacotes inequivocamente rotulados, prontos para serem cultivados nos jardins apropriados. (MARSHALL, 2002, p. 54-55, grifos do autor).

Para Marshall, como assinalado, o impacto dos direitos da cidadania sobre a estrutura da desigualdade social não é somente o de remodelar o nível do piso do porão do 
edifício social, deixando a superestrutura como se encontrava antes. Para ele, ao menos naquela época que encobria o ano de 1949, havia um movimento dos direitos da cidadania por igualdade absoluta que começava a remodelar o edifício inteiro e que poderia acabar transformando um arranha-céu num bangalô. Intrigado em saber se havia qualquer limitação a esse movimento, Marshall (2002, p. 64-65) é categórico em afirmar não somente sobre a existência de uma limitação, mas de apontar o sistema econômico como sendo a sua fronteira. Evidentemente que ele concebe o sistema econômico como já abarcando a justiça social, tanto que continua dizendo que o movimento em favor de uma igualdade absoluta é acionado por dois diferentes instrumentos, o da cidadania, baseado exclusivamente na justiça social, e o sistema econômico, que é a justiça social combinada com a necessidade econômica. Nos dois casos o objetivo é um só: eliminar desigualdades que não podem ser consideradas legítimas (MARSHALL, 2002, p.65). E arremata:

A civilização unificada que torna as desigualdades sociais aceitáveis, e ameaça deixá-las sem função do ponto de vista econômico, é alcançada por um divórcio progressivo entre as rendas real e nominal. Isto está, evidentemente, explícito nos serviços sociais de maior monta, tais como saúde e educação, que oferecem em espécie sem nenhum pagamento ad hoc. (MARSHALL, 2002, p. 68, grifos do autor).

Marshall adota tal posicionamento porque a sua preocupação não é classe social e sim status. Isto perpassa todo o seu livro de maneira clarividente ${ }^{21}$. Ademais, ele já tinha alertado, talvez de modo menos implícito do que alguns gostariam, que procuraria conciliar os princípios do capitalismo e da cidadania ${ }^{22}$, que, em sua opinião, no século XX estavam em conflito. A fórmula encontrada foi o equilíbrio econômico.

Com relação a Castel, a desigualdade criadora pode ser vista, também, a partir daquelas conclusões anteriores, quais sejam, de que, em primeiro lugar, o direito de livre acesso ao mercado de trabalho fez com que a pobreza só pudesse ser atribuída aos próprios pobres; e, em segundo lugar, que o direito social de combate à pobreza advindo do liberalismo provocou a existência de desigualdade entre os próprios pobres, pois, havendo dois tipos de

\footnotetext{
${ }^{21}$ Sobre a posição secundária de classe social pelo próprio Marshall, ver cap. 2, “o impacto inicial da cidadania sobre as classes sociais" (MARSHALL, 2002, p. 23-37).

22 "Se estou certo ao afirmar que a cidadania tem sido uma instituição em desenvolvimento na Inglaterra pelo menos desde a segunda metade do século XVII, então é claro que seu crescimento coincide com o desenvolvimento do capitalismo, que é o sistema não de igualdade, mas de desigualdade. Eis algo que necessita de explicação. Como é possível que estes dois princípios opostos possam crescer e florescer, lado a lado, no mesmo solo?" (MARSHALL, 2002, p. 24).
} 
pobres, o direito social de combate à pobreza é destinado somente aos que não podem trabalhar. Contudo, ele se interroga:

[...] os operários deveriam compreender que seu "verdadeiro interesse" não consiste em estarem garantidos contra a miséria através de um salário seguro mas, sim, em esposar a ideologia liberal que os coloca em situação de concorrência, remunera as "faculdades" e os "talentos", penaliza os medíocres e os fracos. Mas por que entrariam eles, de livre e espontânea vontade, nessa lógica concorrencial que, realmente deviam pressentir, iria deixá-los nas mãos dos empregadores? (CASTEL, 2003, p. 263, grifos do autor).

Castel (2003, p.265) revela que sua resposta para essa indagação é baseada na concepção de um capitalismo utópico, que ele explica da seguinte maneira: os reformadores ${ }^{23}$ vivenciavam, em profunda intensidade, a ambigüidade real existente naquela época. E teriam levado ao extremo as características dinâmicas do progresso econômico e social que alguns setores, regiões e pontos específicos da sociedade estavam gozando com a adoção do novo sistema ${ }^{24}$. Na verdade, os reformadores sequer podiam prever que, paralelamente ao progresso, haveria altas e custosas contrapartidas sociais, que, repita-se, não eram plenamente perceptíveis naquele momento histórico. Portanto, Castel se associa à idéia do pleno domínio da razão nas transformações sociais e econômicas, inclusive os efeitos da revolução científica, apenas e tão-somente para procurar entender os revolucionários burgueses. Neste passo, há como pressuposto implícito o estreito vínculo entre a ciência e a técnica com a idéia do livre mercado, cuja justificativa decorre do fato de que no mercado se condensam as idéias da individualidade e da concorrência, centrais para o desenvolvimento da ciência e da técnica, mas também porque a ciência e a técnica serão transformadas em força de produção, elemento essencial para o capitalismo ${ }^{25}$. Neste específico ponto existe uma divergência com o posicionamento de Castel, pois ele é enfático ao dizer que, "a uma leitura cínica (a burguesia ascendente manipulou tudo em função do seu interesse), prefiro uma outra que permite recolocar esse episódio revolucionário no longo prazo e que introduz uma melhor compreensão das futuras peripécias da questão social” (CASTEL, 2003, p. 265). De fato, as análises simplórias devem ser afastadas, no caso, de que a burguesia foi capaz de tudo

\footnotetext{
${ }^{23}$ Como Castel passa a chamar os liberais neste ponto do seu texto.

24 "Os promotores da modernidade propuseram-se estender para o corpo social inteiro os benefícios de transformações que observavam em setores ainda limitados. Extrapolaram uma dinâmica ainda em gestação. Exatamente nisto é que consiste o caráter "utópico" de sua construção. Não descrevem um estado geral mas projetam em dimensões mundiais a realização de um processo que, se deixou de ser marginal, permanece obstruído por todas as heranças, quer se trate das estruturas políticas, das regulações jurídicas, das formas de explorar a terra ou de fazer os homens trabalharem". (CASTEL, 2003, p. 268, grifos do autor).

${ }^{25}$ Cf. SANTOS, Boaventura S. Pela mão de Alice: o social e o político na pós-modernidade. São Paulo: Cortez Editora, 2005 (ver capítulo 6 que trata do tema aqui ventilado).
} 
manipular. Contudo, apreendendo-se o próprio pensamento de uma época como enraizado nas próprias condições materiais em que ele está inserido, adveio a pergunta inicial: de que modo as condições materiais da época constituíram o direito social de combate à pobreza? Ao contrário de Castel, para nós esse critério possibilita uma resultante muito mais compreensiva da realidade.

Entretanto, tangenciando tal divergência, muito embora fique enfraquecida a argumentação de Castel, é possível conceber o seguinte: a colcha de retalhos que encobre a revolução científica e o capitalismo, muitas vezes gerando uma indevida associação entre $\operatorname{ambos}^{26}$, é decorrência das condições materiais daquela época, ou seja, o fenômeno de ruptura do feudalismo é situado no tempo e no espaço e só poderia ter emergido do liberalismo econômico e político. Com efeito, há para Castel, assim como para os juristas defensores da evolução de direitos fundamentais e para a teoria da cidadania de Marshall, a conhecida relação de causa e efeito, no caso, entre a ruptura do Antigo Regime através da implantação do liberalismo, ratificada via a revolução industrial e científica, com a questão social. É daqui que nascerá o nexo causal indicativo do direito social de combate à pobreza como decorrência do próprio modo como o liberalismo enfrentará essa questão social. Evidentemente que não no sentido de uma estratégia política de dominação e disputa de poder, pois isto implicaria em um modo cínico, como disse o próprio Castel, de entender a história. Pelo contrário, o liberalismo econômico e o liberalismo político conceberam o direito social para enfrentar a questão social. E assim foi feito porque o Estado social toma nota dos efeitos perversos das regulações puramente econômicas e da insuficiência das regulações morais ${ }^{27}$. Ele não é expressão de um voluntarismo político (CASTEL, 2003, p. 278). E aqui é enfático:

[...] os dispositivos específicos desenvolvidos em nome da solidariedade são outros tantos meios de evitar a transformação diretamente política das estruturas da sociedade. Que cada um fique em seu lugar, mas que haja um lugar. [...] o Estado social, em sua filosofia como em seus modos de instrumentalização prática, é um compromisso. Compromisso entre os interesses do mercado e as reivindicações do trabalho. [...] Mas o Estado social é também um horizonte. A perspectiva histórica mostra que é a forma - porém a forma variável - que o compromisso entre a dinâmica econômica, comandada pela busca do lucro, e a preocupação de proteção, comandada pelas exigências da solidariedade, assume". (CASTEL, 2003, p. 278-280).

Portanto, longe do direito social de combate à pobreza, consubstanciado em Castel via o Estado social, ser uma mera resposta ou contraponto à sociedade capitalista ou ao

\footnotetext{
${ }^{26}$ Ambos os pressuposto são admitidos apenas por serem os adotados por Castel.

${ }^{27}$ Daí a divergência entre Castel e o fio condutor deste trabalho, que é baseado na perspectiva política e conflituosa das relações sociais.

PRISMAS: Dir., Pol.Pub. e Mundial., Brasília, v.3, n, 2, p. 395-426, jul/dez.2006 
liberalismo, tem-se um compromisso interno da sociedade capitalista. É enquanto pacto entre o livre mercado e os trabalhadores que se pode compreender que o direito social de combate à pobreza só poderia ter emergido do liberalismo econômico e político. Nesta perspectiva, o direito social de combate à pobreza é também fruto de um processo evolutivo. A evolução fez com que no bojo da sociedade capitalista, que rompeu com o Antigo Regime, um compromisso fosse acordado, tanto que Castel indica em todo o seu livro que o Estado social é $o$ nosso horizonte. É bem verdade, que tal processo pouco difere tanto da concepção de evolução dos direitos fundamentais como da concepção de cidadania de Marshall, pois, de fato, não se trata de apenas superar uma etapa anterior, através de pseudo-antagonismos. Muito além disso, Castel indica uma síntese, vez que é isso que a idéia de compromisso entre mercado e trabalhadores claramente indica.

Assinala-se que não será analisada a conotação idílica desse compromisso entre os interesses do mercado e as reivindicações dos pobres e trabalhadores, seja porque não é o foco deste trabalho, seja porque tal compromisso deveria ser submetido ao mesmo questionamento crítico, no caso, ser indagado o motivo pelo qual dado compromisso surgiu, e não um outro, em dado momento. E questionar, no presente, o motivo do rompimento desse compromisso. De qualquer maneira, o direito social de combate à pobreza, derivação direta desse compromisso apontado por Castel, indica que a pobreza é até encarada como objeto do conjunto das relações sociais, mas não é posta em questão a desigualdade social e o complexo de valores e normas sociais que amparam essa desigualdade. Ao contrário, se uma das partes que firma o compromisso é o interesse do mercado, "comandada pela busca do lucro" (CASTEL, 2003, p. 280), nenhuma ação ou atitude contra o compromisso pode ser aceita sem que isso corresponda a uma tentativa de rompimento, ou melhor, de desfazimento do acordo. É intocável, então, os processos econômicos, jurídicos, culturais, políticos, etc. que outorgam materialidade à desigualdade social. Aliás, a idéia de Estado social como resultado de um compromisso entre mercado e trabalhadores, ao menos subliminarmente, indica que o próprio Castel reconhece legitimidade aos princípios indispensáveis à implantação do capitalismo, já que, por exemplo, sem o direito de livre acesso ao trabalho os indivíduos não poderiam participar livremente do mercado de trabalho, como vendedores da força de seu trabalho. Conseqüentemente, no final das contas, a desigualdade provocada pelo capitalismo, na medida certa e diante de um Estado social que tem forma variada, é vista como elemento essencial, que beneficia a sociedade. 
Portanto, seja amparando-se em Marshall, seja nas linhas anteriores sobre Castel, aprofundou-se um pouco mais a questão do direito social de combate à pobreza, mostrando dois aspectos pouco difundidos - ou estrategicamente considerados como tão óbvios que dispensariam comentários e análises -, quais sejam, o isolamento do direito social do conjunto de relações sociais e o fato desse direito social ser fonte de desigualdade social e legitimar essa desigualdade. E isto anuncia que o direito social é amigo da pobreza, mas está distante do pobre.

\section{Considerações finais: 0 direito social amigo do pobre e distante da pobreza}

A formulação do presente tópico final em considerações tem o significado claro de alertar que o presente trabalho é um início e está aberto às novas investigações que ainda serão demandadas, ou para tentar responder alguns questionamentos que aqui não foram argüidos e outros decorrentes do aprofundamento das investigações, tais como, sobre a atuação ativa dos pobres nas ações sociais para a conquista da emancipação e a construção de sujeitos sociais, ou, ainda, a relação entre o pensamento liberal com a doutrina social da Igreja. Contudo, foi apresentada uma alternativa de leitura aos chamados direitos fundamentais de segunda geração e à própria relação entre direito social e questão social, sendo que foram apontadas duas características básicas ao direito social à assistência social a partir das idéias liberais: a primeira, no sentido de que o direito social é visto como isolado do sistema de relações sociais; a segunda, no sentido de que ele é fonte de legítima desigualdade social.

De fato, mostrou-se que para Marshall há uma evolução na noção dos direitos de cidadania, via uma intensiva progressão desses direitos, que finda por gerar, em um segundo momento, que essa ascensão seja fonte de inquietação, daí porque ele busca defender limites e evitar excessos. O direito social não deve extrapolar a sua função de minimizar o fosso da pobreza e reduzir a distância entre as classes sociais. Ao respeitar princípios econômicos, ele é fonte de uma desigualdade permitida, que traz benefícios para o corpo social. Por fim, é bom lembrar que Marshall também noticiou que em sua origem o direito social exerceu uma dupla função, ora servindo de obstáculo ao capitalismo, ora servindo para absolver o capitalismo de qualquer responsabilidade para com a pobreza.

Castel nos historiou como o reconhecimento da vulnerabilidade das massas e a imperiosa necessidade de liberdade de acesso ao trabalho serviram de bandeira contra as regulações e tutelas do trabalho consubstanciadas pelo feudalismo. E de como essa pobreza 
em massa passou a ser atribuída à existência de obstáculos a uma sociedade de livre mercado, o que provoca pensamento sobre a flexibilização das atuais políticas de relação trabalhista. Chamou-se atenção para uma convergência entre Marshall e Castel no que toca a existência de um direito social antes da existência propriamente de um direito social como hoje ele é concebido, ao menos pela figura de uma preocupação legislativa para com a pobreza e o indigente. Ambos os autores aduziram como esse prematuro direito social serviu de impedimento para o desenlace das idéias liberais. De qualquer modo, consagrada a ruptura com o Antigo Regime, o combate à pobreza não ficou resolvido com o simples direito de acesso ao trabalho, justamente porque não foi assegurado direito a um trabalho. No bojo dos debates que Castel contou, restou claro que qualquer ação nesse sentido era considerada um retrocesso ao livre jogo do mercado. O agravamento da crise encadeou o aparecimento do Estado social e, conseqüentemente, dos direitos sociais, baseado no compromisso entre o interesse do mercado e o interesse dos trabalhadores.

Assinalou-se que há convergência entre as análises de Marshall, de Castel e a teoria da geração de direitos fundamentais, qual seja, elas não questionam a pobreza como fruto da desigualdade social, baseada em valores e normas, ou sequer através dos processos econômicos e de ações políticas que viabilizam e legitimam essa desigualdade. Assim, todos findam por legitimá-la. É um direito amigo da pobreza, pois dela se serve, mas longe do pobre. A rigor, Marshall e Castel reconhecem e identificam as relações que provocam desigualdades, mas não questionam seu fundamento. Marshall, de fato, reconhece de modo explícito que algumas desigualdades são permitidas, e que elas são derivadas de um processo racional de planejamento, orientado pela economia, evitando-se majorar a inadvertida equação que passou a condicionar o direito universal à renda real do beneficiado. Por sua vez, é através do chamado compromisso entre o interesse do mercado e o interesse dos trabalhadores, fundamento do Estado social, que Castel implicitamente abraça a tese de que qualquer tentativa de igualdade absoluta iria contrariar interesses de uma das partes, o que refletiria um rompimento do pacto. Pode-se entender aqui por tentativa de igualdade absoluta aquele movimento do direito social que preocupou Marshall, no sentido de que este direito buscou fazer do edifício social estruturado em desigualdades um piso térreo, similar a um bangalô.

Vale acrescer que Castel denuncia a maneira como a modernidade liberal irá tratar a questão social, ratificando a tradicional divisão dos pobres em válidos e inválidos. E como o Estado social continua sendo "a nossa única herança e horizonte" (CASTEL, 2003, p. 279), o 
catálogo descritivo entre pobre e extremamente pobre para enfrentar à pobreza é legitimado. Por seu turno, o fato de que ao menos há o reconhecimento do combate à pobreza como um direito de cidadania, o que evitará a colocação ou permanência de alguns indivíduos em condições de vulnerabilidade, não exime ou anula o elemento danoso que destrói o direito social que classifica o cidadão entre o que pode e o que não pode trabalhar, via um violento estigma. O ponto nevrálgico continua sendo o silêncio sobre o perímetro do direito de acesso ao trabalho que não extrapola para o direito a um trabalho. Isto faz com que àquela denúncia de Castel sobre o trabalho livre e o acesso a um trabalho possa ser respondida ou contraposta pela advertência de Marshall do impacto da noção dos direitos de cidadania sobre a estrutura da desigualdade social e a tão preciosa atenção com a harmonia entre a justiça social e a necessidade econômica.

Este trabalho, principalmente, acentuou que tanto a pobreza como o direito social não são fenômenos atomísticos no meio da sociedade. Eles fazem parte da própria armação ou esqueleto da sociedade, daí o motivo pelo qual não se deve escamotear a questão envolvida que perpassa a forma e o modo como dada sociedade relaciona-se em suas diversas esferas (econômica, política, jurídica, social e cultural), além de circundar a questão a um controle social que não afete e altere o padrão de funcionamento dessa sociedade (DEMO, 2000, p. 30), tanto que dentro da lógica histórico-estrutural da desigualdade social, prefere-se o beneficiário ao invés do cidadão, porque, de um lado reproduz-se com elegância a ignorância e, por outro lado, fantasia-se utilidade imediatista dos agentes da política social, em particular da pública (DEMO, 2000, p. 31).

A maneira como foi apresentada a relação entre a questão social e o direito social de combate à pobreza e o fato do direito social ser isolado das relações sociais e legitimador de desigualdades, ambos sugerem que os resultados políticos, mensurados em termos de controle social aumentado e até de legitimação dos governos, seriam pífios. Todavia, adotando-se posicionamento igual ao de Salama e Valier (1997, p. 126), a realidade mostra que esse direito social de combate à pobreza é bem recebido pela sociedade. Sua força consiste em sua coerência com a política de liberalismo econômico. E, recebidas como benéficas, o direito social de combate à pobreza do liberalismo pode contribuir para inibir os movimentos sociais e para constituir a prova de uma certa eficiência em termos de legitimação dos governos (SALAMA; VALIER, 1997, p. 126). Atualmente, caso se compreenda que as políticas sociais neoliberais consistem na manifestação de uma vontade de estabelecer um pacto social com as camadas mais pobres, como sugere Castel, quiçá com o 
intuito de limitar os conflitos sociais e de encontrar certa legitimidade junto a essas camadas, pode-se dizer que elas alcançaram um certo êxito.

O aprofundamento da pobreza parece operar uma situação inusitada e muito perversa, pois favorecem as forças ou coalizões políticas de inspiração neoliberal. Como nos diz Boron (2000, p. 168), é preocupante uma situação em que parece que o neoliberalismo descobriu a alquimia política que lhe permite uma duração sustentada para a implantação de sua reacionária política de recomposição da acumulação. Paradoxalmente, o tão difundido conceito de cidadania e aquela preocupação de caráter econômico de Marshall ensejam, ambos, que o direito social de combate à pobreza seja destinado aos extremamente pobres. Ademais, essa tese da equivalência entre a renda real do cidadão, apurada com base em valor de mercado, e o direito universal a ele dispensado, atualmente, por exemplo, justificaria o corte e redução dos gastos sociais por parte do Estado. Aliás, o Estado social de Castel mantém a conciliação entre, de um lado, os pobres que podem trabalhar e os pobres que não podem trabalhar, com o outro lado, o do interesse do mercado, que é único e segue a lógica do lucro.

Portanto, a partir daquela mesma formulação de Boron (2000, p. 168), é possível admitir que o direito social de combate à pobreza não só persegue o objetivo básico de uma sociedade capitalista, qual seja, o de concentrar riqueza e renda nas mãos do capital, senão também de fomentar a dependência e subordinação política das classes pobres, cujo efeito é tornar inofensivas as conseqüências da cidadania. Afinal, não se pode esquecer o papel que o empobrecimento da classe trabalhadora desempenha ao perpetuar a sua subordinação às elites dominantes (BORON, 2000, p. 168). Quando a pobreza chega a certos extremos o recurso implícito da venda do voto se converte em uma estratégia maior de sobrevivência, pois os que estão caindo fora da sociedade, para usar uma expressão do professor e político Darcy Ribeiro, não têm outro remédio senão apoiar os governos, caso não queiram ver interrompido o incerto e precário, mas essencial, fluxo assistencialista a que são submetidos (BORON, 2000, p. 168). O direito social de combate à pobreza, assim, não é amigo dos pobres, mas da própria pobreza.

Artigo recebido em agosto de 2006

Aceito para publicação em outubro de 2006

\section{Referências}


ABRANCHES, Sérgio H. Política social e combate à pobreza: a teoria da prática. In: Santos, Wanderley G.; COIMBRA, M. Política Social e Combate à Pobreza, 4. edição, Rio de Janeiro: Zahar, 1998, cap. 5.

ARAÚJO, Cláudia de R. M.O direito de resistência na constituição federal 1988. In: $\mathbf{O}$ direito constitucional de resistência.Porto Alegre:Sergio Antonio Fabris Editor, 2002, cap. VI, p.81-87.

BERMAN, Harold J. La formación de la tradición jurídica de occidente. Mexico: Fondo de Cultura Económica, 1996.

BOITO JR., Armando. A hegemonia neoliberal no governo Lula. Revista Crítica Marxista, Rio de Janeiro, n. 17, 2003. Disponível em < http: // www. unicamp. br / cemarx / criticamarxista / sumario 17. html >. Acesso em 22 nov. 2003.

BORON, Atílio A. Problemas estructurales y desafíos estratégicos de la izquierda: una mirada desde la Argentina. In: ___ Trás el búho de minerva: mercado contra democracia en el capitalismo de fin de siglo. Buenos Aires: Fondo de Cultura Económica; Consejo Latinoamericano de Ciencias Sociales, 2000.

BRASIL. Constituição (1988). Constituição da República Federativa do Brasil: promulgada em 5 de outubro de 1988. Organização do texto: Juarez de Oliveira. 4. ed. São Paulo: Saraiva, 2006. 168 p. (Série Legislação Brasileira).

CARVALHO, Inaiá Maria M. Brasil: reestruturação produtiva e condições sociais. Caderno CRH, Salvador, n. 35, p. 123-149, jul./dez. 2001

CASTEL, Robert. As metamorfoses da questão social: uma crônica do salário. 4. ed. Petrópolis: Editora Vozes, 2003.

CEPAL, 1998, San Jose. El desarrollo social en los años noventa: principales opciones. San Jose: División de Desarrollo Social, [S.I:s.n], 1998.

CITTADINO, Gisele. Pluralismo, direito e justiça social: Elementos da filosofia constitucional contemporânea. São Paulo: Lúmen Júris, 1999.

COGGIOLA, Osvaldo. Governo Lula: da esperança à realidade. 1. ed. São Paulo: Editora Xamã, 2004.

DANTAS, Fernando.Cai concentração de renda no Brasil, mostra BIRD. O Estado de São Paulo, São Paulo, 27 abr. 2006. Disponível em < hppt://www.e-agora. org. Br / imprimir. php?id=4025_0_29_0>. Acesso em 23 mai. 2006.

DANTAS, Ivo. Direito constitucional econômico: Globalização e constitucionalismo. Curitiba: Juruá editora, 1999.

DEMO, Pedro. Sociologia: uma introdução crítica. 2. ed. São Paulo: Editora Atlas, 1987.

Combate à pobreza: desenvolvimento como oportunidades. Campinas: Autores Associados, 1996. (Coleção educação contemporânea) 
Política social do conhecimento: sobre futuros do combate à pobreza. 2. ed. Petrópolis: Editora Vozes, 2000.

Pobreza da pobreza. Petrópolis: Editora Vozes, 2003.

DRAIBE, Sônia M. As políticas sociais brasileiras: diagnóstico e perspectivas. Para a Década de 90 Prioridades e Perspectivas de Políticas Públicas, Brasília, v. 4, p. 1-66, mar.1990. Paginação irregular.

FARAH, Marta F.S. Parcerias, novos arranjos institucionais e políticas públicas locais. Revista de Administração Pública, São Paulo, v. 18, n.1, p. 119-145, jan./fev. 2001.

FARIA, José Eduardo (Org). Direito e globalização econômica: implicações e perspectivas. São Paulo: Malheiros editores, 1996.

FERREIRA, Aurélio B. de H. Novo dicionário da língua portuguesa. 2. ed. rev. aum. Rio de Janeiro: Ed. Nova Fronteira, 1986.

FONSECA, João B. L. Direito econômico. São Paulo: Forense, 1995.

LEAL, Roger S. Direitos sociais e a vulgarização da noção de direitos fundamentais. Revista do Programa de Pós-Graduação em Direito - UFRGS, Porto Alegre. Disponível em: $<$ http://www6.ufrgs.br/ppgd/doutrina/leal2.htm>. Acesso em: 4 jul. 2006.

KRELL, Andréas J. Direitos sociais e controle judicial no Brasil e na Alemanha: os (des) caminhos de um direito constitucional comparado. Porto Alegre: Sergio Antonio Fabris Editor, 2002.

MARQUES PEREIRA, J. Os limites do Estado na América Latina: cidadania, intervenção social e crise econômica. Cadernos da América Latina, São Paulo, n. 14, nov./dez. 1993.

MARSHALL, T.H. Cidadania e classe social. 2. ed. Brasília: Senado Federal; Centro de Estudos Estratégicos-CEE/MCT, 2002. (Coleção Leituras sobre a Cidadania, v. 1).

MARTINE, George. A resolução da questão social no Brasil: experiências passadas e perspectivas futuras. Para a Década de 90 Prioridades e Perspectivas de Políticas Públicas, Brasília, v. 4, p. 97-128, mar.1990. Paginação irregular.

MIAILLE, Michel. Uma introdução crítica ao direito. 2. ed. Rio de Janeiro: Moraes editores, 1979.

NETO, Diogo F. M. Globalização, regionalização, reforma do Estado e da constituição. Revista de Direito Administrativo, São Paulo, v. 211, p. 1-20, jan./mar. 1998.

OLIVEIRA, Ariovaldo U. O programa fome zero e o ronco da cuíca. Revista ADUSP, São Paulo, V.3, n. 29, p. 20-27, abr. 2003.

POCHMANN, Márcio. Razões da desigualdade no Brasil. Carta Maior, São Paulo, 23 mai. 2006. Disponível em $<$ hppt: // www. cartamaior. uol. com. br/ templates/ colun $\backslash$ Imprimir. Cfm ? coluna_id $=2216>$. Acesso em 23 maio 2006. 
REALE, Miguel. O Estado democrático de direito e o conflito das ideologias. São Paulo: Saraiva, 1998.

REIS, Fábio W. Cidadania democrática, corporativismo e política social no Brasil. Para a Década de 90 Prioridades e Perspectivas de Políticas Públicas, Brasília, v. 4, p. 161-196, mar.1990. Paginação irregular.

ROSSI, Clóvis. O neocoronel. Folha de São Paulo, São Paulo, 28 fev. 2006. Disponível em: $<$ http://www1.folha.uol.com.br/fsp/indices/indice28022006.htm>. Acesso em: 28 fev. 2006.

SALAMA, Pierre; VALIER, Jacques. Pobrezas e desigualdades no $3^{\circ}$ Mundo. São Paulo: Livraria Nobel, 1997.

. Neoliberalismo, pobrezas y desigualdades en el Tercer Mundo. Buenos Aires: Minõ y Davila editores, 1999.

SADER, et. al. Governo Lula: decifrando o enigma. 1. ed. São Paulo: Editora Viramundo, 2004.

SAES, Décio A. de M. Cidadania e capitalismo: uma crítica à concepção liberal de cidadania. Revista Crítica Marxista. Rio de Janeiro, $\mathrm{n}^{\mathrm{o}}$ 16, 2003. Disponível em < http: // www. unicamp.br/cemarx/criticamarxista/sumario17.html >. Acesso em 15 nov. 2003.

SUÁREZ, Fernando. Los derechos sociales em las constituciones. In: Constitucion y economia: la ordenación del sistema economico en las constituciones occidentales. Madri: Centro de Estudios y Comunicación Económica, 1977, p. 201-215.

VUOLO, R. et al. La pobreza .... de la politica contra la pobreza. 2. ed. Buenos Aires: Minõ y Davila editores, 2004.

Prefacio. In: SALAMA, Pierre; VALIER, Jacques. Neoliberalismo, pobrezas y desigualdades en el Tercer Mundo. Buenos Aires: Minõ y Davila editores, 1999, p. 8-19. 


\section{Resumo}

Este texto busca fazer crítica ao direito social de combate à pobreza a partir de um diálogo com a teoria da cidadania de T. H. Marshall e a modernidade liberal de Robert Castel, construindo uma reflexão sobre direito social e a pobreza.

Palavras-Chave: Pobreza. Políticas públicas. Liberalismo. Direito social.

\section{Abstract}

This paper reviews the social rights from a dialog with the teory of citizenship from $\mathrm{T}$. $\mathrm{H}$. Marshall and the modern liberalism of Robert Castel, building a thought about social rights and poverty.

Key words: poverty. Publice policies. Liberalism. Social rights. 